\title{
CARÁTER, EMOÇÃO E JULGAMENTO NA RETÓRICA DE ARISTÓTELES
}

\author{
MARIA DE FÁTIMA SIMÕES FRANCISCO* \\ Faculdade de Educação \\ da Universidade de São Paulo
}

\begin{abstract}
RESUMO: Na sua teoria da arte retórica Aristóteles identifica três tipos de provas pelas quais o orador persuade. Interessa-nos investigar duas dessas provas - aquela pelo caráter do orador e aquela pela emoção do ouvinte - e entender de que maneira elas estão relacionadas à situação de julgamento na qual atua o orador. Essa situação é analisada em alguns de seus aspectos para depois se tentar compreender a justificação aristotélica para a necessidade de seu uso na arte retórica.
\end{abstract}

PALAVRAS-CHAVE: provas; caráter; emoção; julgamento; antilogia; deliberação; investigação; opinião; crença.

A finalidade primeira do discurso retórico é a persuasão. Para alcançá-la o orador deve apresentar provas (pisteis) ${ }^{1}$ que façam a audiência aderir à tese defendida. Dentre essas provas, Aristóteles distingue as não-técnicas (atechnoi) das técnicas (entechnoi). As primeiras são as seguintes: a lei, as testemunhas, os contratos, os depoimentos de escravos extraídos sob tortura, e os juramentos. As provas técnicas, por sua vez, são de três espécies: a prova lógica ou pelo próprio logos (discurso), a prova pelo ethos (caráter) do orador e a prova pelo pathos (emoção) do ouvinte. ${ }^{2} \mathrm{O}$ que faz técnicas essas três provas e as diferencia das primeiras, diz o autor, é o fato de não pré-existirem ao discurso, mas serem elaboradas pelo orador no instante da elocução. São chamadas técnicas, ou seja, estruturadas segundo as regras e os métodos próprios da arte retórica, na medida em que são construídas somente por meios discursivos. Interessa-nos nesse texto centrar nossa atenção nas provas técnicas e, mais precisamente, em duas delas: as provas pelo ethos do orador e pelo pathos do ouvinte, a fim de compreender de que maneira são elas necessárias à arte retórica e como são justificadas na teoria aristotélica acerca dessa arte. 
Se, por um lado, as três provas técnicas resultam igualmente dos procedimentos particulares da arte retórica, e nesse sentido são a mesmo título técnicas, podemos, por outro lado, observar que apenas aquelas duas provas conferem à retórica um lugar especial no conjunto das chamadas técnicas discursivas de verdade. Empregamos essa noção de técnica discursiva de verdade no sentido que lhe dá $\mathrm{F}$. Wolff. ${ }^{3}$ São assim denominadas por ele três técnicas do período grego clássico - a ciência, a dialética e a retórica - que, de um lado, se valem de meios discursivos para a realização de seus fins e, de outro, visam por tais meios produzir no interlocutor um efeito de verdade. O singular acerca da retórica é que, para perseguir seu fim - a produção de uma convicção de verdade por via da persuasão, faz recurso não apenas à prova lógica - a partir de cujo ponto de vista seria, por assim dizer, idêntica àquelas técnicas -, mas também a outras duas provas, aquelas pelo ethos e pelo pathos, que nenhum equivalente possuem na ciência e na dialética. Esse seria, a nosso ver, um dos principais traços a distinguir e singularizar a retórica frente às outras duas técnicas discursivas de verdade.

Na medida em que a retórica é uma técnica discursiva de verdade essas duas provas, tanto quanto a prova lógica, têm por finalidade produzir no ouvinte uma convicção de verdade, isto é, fazê-lo admitir como verdadeira certa tese defendida pelo orador acerca do caso em discussão. Entretanto, enquanto a prova lógica busca essa finalidade por recurso à apresentação de razões que conduzem o ouvinte à admissão da verdade dessa tese, as provas pelo ethos e pelo pathos o fazem por meios inteiramente diversos. Elas, por assim dizer, atuam sobre o ouvinte, criando nele seja uma imagem do orador como pessoa digna de ser acreditada, seja um estado emocional favorável àquele, de maneira a levá-lo também à admissão da verdade da mesma tese. O que parece estar, portanto, em jogo nessas duas provas é a produção no interlocutor de uma convicção de verdade, mas não exclusivamente através de meios puramente argumentativos ou lógicos. ${ }^{4}$ Entendemos por estes o uso do entimema e do exemplo, isto é, a apresentação de premissas que permitam sustentar a verdade de uma conclusão. Poderíamos então dizer que aquelas duas provas se dirigiriam, na psicologia aristotélica, não apenas à parte racional da alma do interlocutor, mas também à outra parte desta, a nãoracional. ${ }^{5}$ Tal fica claro por exemplo na prova pelo pathos, onde se trata de dispor emocionalmente o ouvinte de modo a torná-lo favorável à tese defendida pelo orador. Sabemos que a faculdade de ser afetada pelas paixões (pathe) é atributo próprio da parte não-racional da alma. Por outro lado, também na prova pelo ethos a parte nãoracional da alma estará sendo mobilizada. Pois o objetivo do orador é o de despertar no ouvinte basicamente um sentimento: o de ser digno de sua confiança (axiopistos), a fim de ser por ele acreditado. ${ }^{6}$ 
É nossa intenção nesse texto sugerir que as provas pelo ethos e pelo pathos são em boa parte as responsáveis pelo caráter específico da retórica relativamente às outras duas técnicas discursivas de verdade, que a ela se assemelham em muitos pontos. Parece-nos que o exame de um aspecto fundamental, intimamente relacionado com a existência dessas duas provas na retórica, pode nos fazer entender melhor a especificidade dessa arte. Trata-se do tipo particular de inserção institucional realizado por ela. Sabemos que a retórica é a única das três técnicas discursivas de verdade a ter uma dimensão política, por ser exercida no espaço público, e mais propriamente no interior das duas instituições maiores do regime democrático - a assembléia e o tribunal -, onde o povo se reúne para julgar dos assuntos de seu interesse e dos particulares. É interessante notar que o espaço institucional em que se inserem as três técnicas discursivas mereceu atenção especial nas análises de Aristóteles. Esse aspecto, é necessário lembrar, não passou tampouco desapercebido a Platão, que ressalta, como elemento primordial de diferenciação entre a dialética e a retórica, o fato de que uma ocorre entre dois interlocutores em reuniões privadas, ao passo que a outra ocorre entre um locutor e uma multidão de ouvintes em reuniões públicas. ${ }^{7}$ É notável ainda que a atividade de ensino da ciência, a terceira técnica, se desdobra igualmente fora do espaço público.

Ora, o filósofo vai justificar a necessidade para a retórica de operar com as provas pelo ethos e pelo pathos também por sua inserção no interior das instituições políticas maiores da cidade. Diz-nos ele: "Uma vez que a retórica tem por finalidade um julgamento (as pessoas julgam o que é dito na deliberação e os procedimentos judiciais são também um julgamento), é necessário não apenas atentar para o argumento, que seja demonstrativo e persuasivo, mas também construir uma imagem de si como pessoa de um certo tipo e preparar o juiz", 1377b20-24. É o fato fundamental de que uma atividade específica, um julgamento, está em curso nas instituições públicas da assembléia e do tribunal, onde tem lugar a prática retórica, que torna necessário, além da prova lógica, o uso das provas pelo ethos e pelo pathos. Existem, na circunstância do julgamento deliberativo e judiciário, elementos tais que fazem insuficiente o uso da prova lógica para se obter a adesão do ouvinte à tese que se lhe propõe, razão por que se demanda o uso daquelas duas outras formas de persuasão.

Reforçando ainda essa idéia, o autor sugerirá numa outra passagem, 1391b722, a ser comentada a seguir, que o emprego da prova pelo ethos é exigido em razão das condições implicadas na situação de julgamento. Antes de discutirmos, portanto, de que maneira a situação de julgamento demanda e justifica o uso das provas pelo ethos e pelo pathos, é importante nos determos na noção rica em significações no texto da Retórica que é a de julgamento. 
Na passagem que vimos de referir, 1391b7-22, num longo raciocínio, após estabelecer que "uma vez que o uso do discurso persuasivo está dirigido a um julgamento", que "um juiz é, por assim dizer, simplesmente alguém que deve ser persuadido" e acrescentar que "somente é juiz, no sentido estrito do termo, aquele que julga as questões em disputa no debates cívicos", o filósofo conclui chamando a atenção para a importância de se tratar do que nomeia "discursos éticos". ${ }^{8}$ Interpretamos essa passagem, tanto relevante quanto difícil, em traços gerais da maneira que segue. A função do discurso que está em causa numa situação de julgamento é a persuasiva. Persuasão e julgamento são, portanto, termos afins, vão sempre juntos, o uso de um pressupõe o do outro. Pode-se falar de julgamento e juiz em dois sentidos: lato (haplos eipein,1391b12) e estrito (holos monos estin haplos krites, 1391b18). Julgamento em sentido lato ocorre em diferentes circunstâncias da vida comum e, grosso modo, sempre que se deve decidir acerca de algo em que parece estar envolvida mais de uma possibilidade. Julgamento em sentido estrito tem-se unicamente nos debates públicos da assembléia e do tribunal. O exercício da função persuasiva do discurso na situação do julgamento público exige o uso do discurso ético - termo com o qual o filósofo parece designar neste momento as provas pelo ethos e pelo pathos. Essa passagem, que parece complementar e esclarecer o sentido da anterior, 1377b20-24, é das mais importantes da Retórica e essencial para se compreender a sistematização aristotélica da arte do orador.

O discurso retórico se define assim por sua localização num quadro institucional da cidade, em cujo centro encontramos a atividade de julgar. $\mathrm{O}$ destinatário desse discurso assume, por sua vez, um papel bem determinado: o de juiz. Julgar, contudo nota o autor, não se diz no contexto da assembléia e do tribunal no mesmo sentido em que se diz em outros contextos em que o termo também é aplicado. Apenas nessas duas instituições se diz em sentido estrito. Na passagem resumida acima, 1391b7-22, o filósofo observa ainda que em situações discursivas outras que as dos debates públicos pode-se também dizer que está em curso um julgamento e que o destinatário do discurso é um juiz, em conseqüência do que, pode-se afirmar, está em exercício a função persuasiva do discurso. O que há de comum em cada uma das três situações ilustradas pelo texto é que o ouvinte é posto em juiz de dois discursos contraditórios, dentre os quais deve decidir. Por exemplo, quando se exorta ou se dissuade alguém a fazer algo, ao mesmo tempo defende-se diante dele uma opinião e se ataca a oposta. Esse alguém é posto na condição de juiz, dos dois discursos opostos e da decisão acerca de qual das duas possibilidades de ação é a melhor. Por outro lado, sempre que alguém fala contra uma proposição, usa o discurso para refutá-la e ao mesmo tempo defende a proposição contraditória. O público que o estiver ouvindo será igualmente posto na condição de juiz, desta vez da decisão acerca de qual proposição é a mais razoável, a defendida ou a 
atacada. O próprio ouvinte do discurso epidítico - o gênero retórico cujo fim é o elogio ou a censura -, embora seja de fato apenas um espectador, pode também, de um certo ângulo, ser considerado um juiz. Pois o discurso é composto para ele, acrescenta o filósofo, "tal como se ele fosse um juiz", ou seja, como se não aceitasse imediatamente o que se lhe diz, mas precisasse ser disto convencido, razão pela qual deve-se diante dele defender o que se diz e atacar eventuais opiniões opostas. ${ }^{9}$

Note-se que quando o autor trata, no De Anima, da noção de julgamento no domínio da sensibilidade, tal termo aparece como a faculdade de discernimento, pelos órgãos da sensibilidade, das qualidades sensíveis opostas, o branco e o preto, o doce e o amargo. ${ }^{10}$ Um elemento básico, inerente a toda situação de julgamento, já claro na atividade dos órgãos sensíveis, é portanto, a atividade de discriminação entre opostos. Tal elemento está, já vimos, presente nas três circunstâncias de uso da linguagem persuasiva mencionadas na passagem comentada. Trata-se nelas para o que ouve, o juiz, de discriminar, com vistas a uma decisão, entre dois discursos opostos que the são apresentados, mesmo que tais discursos possam estar representados num só falante. Pois é característico daquele que fala com intenção persuasiva o discurso duplo, ou seja, defender, de um lado, um ponto de vista e atacar, de outro lado, o ponto de vista oposto, assim como é característico daquele que julga e é persuadido ter de discriminar e decidir acerca desse duplo discurso.

Outro componente importante da função persuasiva do discurso, também presente no julgamento em sentido lato, destacado na passagem em exame, é que se julga porque não se sabe: "pois sobre o que sabemos e já julgamos não há mais necessidade de discurso" (1391b7). O juiz se encontra diante de dois discursos opostos, pois tratando estes do que ainda ignora ou sobre o que ainda não tomou partido, qualquer posição que se defenda diante dele, qualquer discurso que se faça para ele, pressupõe sempre a possibilidade da posição e do discurso contrários. Ao mesmo tempo, nenhum dos dois é evidente para o que julga, nenhum dos dois é imediatamente aceitável. Ambos sendo apenas plausíveis, para se obter a adesão do juiz a algum deles é necessário que se o defenda e que o juiz seja dele convencido. Assim, no primeiro exemplo de julgamento em sentido lato, o que ouve alguém exortando-o ou dissuadindo-o de fazer algo se encontra em estado de ignorar como deverá agir. Ele ainda não julgou, não decidiu, não tem, a propriamente falar, um juízo formado acerca do assunto, é esse o sentido da sua 'ignorância'. Da mesma forma, no segundo exemplo, o que ataca uma proposição deve também apresentar a defesa da sua contraditória, porque nenhuma das duas proposições é imediatamente evidente para aquele que as ouve. Por sua vez, o orador no discurso epidítico age como se o ouvinte não tivesse uma opinião definitiva sobre a pessoa ou coisa que elogia ou censura, razão pela qual é possível ainda um discurso 
elogiando ou censurando essa pessoa ou coisa. Em cada um dos três exemplos, desde que se trata de uma situação de julgamento e da função persuasiva do discurso, encontramos um interlocutor que ouve e é juiz de dois discursos opostos, ambos plausíveis para ele que está em estado, por assim dizer, de ignorância da matéria, por não ter ainda decidido, formado um juízo acerca dela. $\mathrm{O}$ juiz se encontra então numa situação de indeterminação, de indecisão, em relação a dois discursos opostos, a duas possibilidades contrárias. Por ser, entretanto, um juiz ele é chamado a se pronunciar, deve decidir, abandonar a situação de indeterminação.

Essas duas dimensões do julgamento em sentido lato - a de discriminação entre opostos e a do não-saber - estudadas pelo filósofo e até aqui descritas, estão, veremos, igualmente presentes no julgamento em sentido estrito, o julgamento civil. Entretanto, assumirão ali maior complexidade, em função dos sentidos adicionais de que o regime democrático impregnará a situação de julgamento. Pode-se dizer que tudo se passa como se o regime democrático houvesse decidido desenvolver e explorar no mais alto grau e para fins políticos e judiciários as potencialidades já envolvidas em qualquer situação de julgamento. Julgamento no sentido mais acabado e próprio do termo é pois tão somente aquele que se reveste de todas as conotações decorrentes da inserção nas duas instituições maiores da democracia, a assembléia e o tribunal. Em outras circunstâncias os termos julgamento e juiz só podem ser empregados em sentido fraco e por analogia ao julgamento civil. Resta-nos saber melhor que constelação particular de sentidos adicionais é essa presente nos julgamentos judiciário e deliberativo. Após esboçar tais sentidos, será necessário retornar a nossa questão precedente, qual seja, a de verificar de que forma o julgamento civil e a função persuasiva do discurso público demandam o uso das provas pelo pathos e pelo ethos .

Para indicar os sentidos adicionais de que o regime democrático revestiu o julgamento judiciário e deliberativo, Aristóteles mobilizará uma série de ricos e complexos conceitos. Todos eles dizendo respeito à mesma coisa, tentando dar conta do que se passa no tribunal e na assembléia quando os cidadãos se reúnem. Todos eles tendo, portanto, o mesmo campo semântico. Cada um pressupondo e remetendo a todos os outros. Como se cada um apenas destacasse um ângulo diferente do mesmo objeto. São eles os conceitos de antilogia, opinião, deliberação, investigação, crença e verdade.

Vimos, pelos três exemplos de julgamento em sentido lato, fornecidos em 1391b7-22, que a atividade de julgar traz em si algumas implicações. Julgar implica, por exemplo, (a) uma certa situação discursiva, isto é, a existência de dois papéis distintos: por um lado, um que fala e persuade, isto é, expõe as possibilidades, e, por outro lado, um que ouve e decide acerca das possibilidades. Implica ainda (b) a circunstância 
da duplicidade de discursos, vale dizer, a existência de dois discursos contraditórios entre si, explicitados ou sugeridos pelo que fala e persuade. E implica por fim (c) que, não sendo evidente ou imediatamente aceitável, para o que ouve e julga, nenhum dos dois discursos contraditórios, em razão de seu próprio estado de ignorância, aquele que fala deve ao mesmo tempo convencê-lo da falsidade de um dos discursos, atacando-o, e da verdade do outro, defendendo-o. Também no julgamento em sentido estrito encontraremos esses três elementos, nele estes assumirão, como dissemos, feição mais complexa e refinada.

O julgamento público é também uma situação discursiva por excelência. A relação entre oradores e público é inteiramente mediada pelo discurso. Temos aí duas posições perfeitamente distintas: a do público e a do orador. Trata-se, estando-se numa posição, a do que julga, de ouvir, e, estando-se na outra, a do que persuade, de falar. Note-se, além disso, que a democracia estipulou no julgamento público posições fixas, uns apenas ouvem e julgam, o público, outros apenas falam e persuadem, os oradores. Os que ouvem são, de início, por assim dizer, passivos: são apenas espectadores da performance discursiva dos oradores. Não são chamados a falar, mas somente a ouvir. Os que falam, por sua vez, são inicialmente ativos: persuadem, qual seja, defendem e atacam, Essas posições, passiva e ativa, logo se invertem, pois os que eram espectadores, devem ao final julgar, decidir, isto é, enunciar uma sentença judiciária ou um decreto político. E os que eram ativos, os que falavam, persuadiam, agora devem se calar e aguardar, pois não têm qualquer poder de julgamento, de decisão. $O$ julgamento público como que acentua e radicaliza os dois papéis originais, falante e ouvinte, da situação discursiva do julgamento comum.

Tal como no julgamento em sentido lato o julgamento público apresenta também a situação da duplicidade de discursos. Aqui, mais uma vez, o julgamento público acrescentará algo aos elementos básicos de qualquer julgamento. Os dois discursos contraditórios serão representados e sustentados em dois partidos distintos, em duas posições fixas, ${ }^{11}$ em dois falantes, o que tem o sentido de fazer mais visível a contraditoriedade dos discursos. Além disso, no julgamento público os dois discursos contraditórios são construídos tendo um ao outro por referência. No gênero judiciário, por exemplo, onde essa dimensão de antilogia é mais notória, os discursos das duas posições, queixoso e réu, devem demonstrar teses perfeitamente opostas sobre os mesmos pontos, aqueles em disputa. ${ }^{12}$ Os dois discursos devem, por assim dizer, dialogar entre si. Deve-se responder a questões levantadas pelo adversário, propor questões ele próprio, tirar implicações das colocações do outro, neutralizar seus ataques, edificar novos ataques etc. A dimensão de antilogia de todo julgamento se encontra dessa maneira ampliada e sofisticada no julgamento público. 
Tal como no julgamento comum, no julgamento em sentido estrito a duplicidade de discursos é possível, porque igualmente nenhum deles é imediatamente aceitável ou evidente para o que julga. Também aí, para que o ouvinte discrimine e decida entre esses discursos opostos, para que aceite um deles, será preciso que seja acerca dele convencido. Será preciso, enfim, que aquele que o apresenta o defenda e ataque o discurso oposto. Mais uma vez, tais dimensões serão incrementadas no julgamento público. Sabemos que o universo no qual se dá o julgamento civil é o da opinião (doxa). De modo enfático, nos diz o texto em 1404a2, que "toda a matéria concernente à retórica está relacionada à opinião". Recordemos ainda que em 1377b17 e 1391 b24 o material apresentado nos capítulos I,4-15 e II,2-17 é constituído justamente de doxai. ${ }^{13}$ É, portanto, de opiniões que se compõem os discursos no tribunal e na assembléia. É do domínio da doxa que se trata neles. Sabemos, a partir de outras fontes, que esta se define por "dizer respeito ao que pode ser diferente do que é" (Metafísica, 1040a1). Porque os discursos no julgamento público dizem respeito ao que sempre pode ser diferente do que é, tanto o discurso que afirma uma tese quanto o que a refuta são plausíveis. Porque têm por objeto o contingente não podem ser evidentes, e para serem aceitos pelos ouvintes devem ser defendidos. A defesa de uma tese não evidente implicando sempre o ataque a sua contraditória. Tal nos permite compreender porque a contraditoriedade de discursos, a antilogia, é uma regra básica no julgamento público e, na verdade, em todo julgamento. Ela enuncia, de um lado, um caráter da própria matéria acerca da qual versam os discursos - isto é, a contingência - e, de outro, uma exigência da própria função persuasiva do discurso, uma vez que persuadir é, por definição, lidar com doxai, ou seja, ter de convencer acerca do que não é evidente por si. A opinião é assim o domínio próprio da retórica - chamada na passagem 1354a30-35 de arte da persuasão dos contrários ${ }^{14}-$, pois nenhuma opinião é aceitável por si só, mas pressupõe sempre a opinião contraditória e para ser aceita pelo ouvinte deve defendida.

Uma outra implicação do julgamento em sentido lato indicada em 1391b7-22 é a de ausência de saber. Somente se julga quando não se sabe, quando não se julgou ainda, quando não se tem um juízo formado a respeito. Todo julgamento será então uma busca de saber. Notemos, entretanto, que apenas o julgamento público assume o sentido, cheio de implicações, de deliberação e investigação. A função da retórica, lembra o filósofo, é tratar das coisas acerca das quais deliberamos (bouleuometha).$^{15} \mathrm{O}$ julgamento da assembléia - mas, notemos, também o do tribunal - assume o caráter de uma deliberação (bouleusis). O que se diz na Ética a Nicômaco acerca da deliberação na alma se harmoniza inteiramente com o que se diz na Retórica acerca da deliberação na cidade. Na Ética a deliberação é definida como uma investigação (zetein) ${ }^{16}$ que tem por 
objeto os atos, e mais propriamente os que estão no poder daquele que delibera. ${ }^{17}$ Do De Anima sabemos que a imaginação deliberativa se caracteriza por decidir entre fazer isto ou aquilo, tomando como medida o melhor. ${ }^{18}$ Trata-se, então, a deliberação de uma investigação acerca de cursos de ação, numa situação em que diferentes alternativas estão dadas e em que se busca a melhor. Sabemos ainda pela Ética que, embora as coisas sobre as quais se delibera, os cursos de ação, aconteçam na maior parte das vezes de uma certa forma, envolvem obscuridade e indeterminação, ${ }^{19}$ o que precisamente explicará o fato de ser objeto de deliberação.

Note-se, por sua vez, que de modo muito semelhante à Ética, na Retórica a deliberação nos é sucessivamente apresentada como tendo por objeto: as ações; o que parece admitir duas possibilidades; o que não é necessário, mas sempre pode ser diferente do que é, tanto no passado quanto no futuro. ${ }^{20}$ Observe-se que a deliberação de que se fala na Ética, a do domínio da alma, a individual, assim como a imaginação deliberativa tratada no De Anima, dizem respeito somente ao futuro, a um curso de ação a tomar. Nesses dois textos a análise filosófica tomou como modelo a deliberação que acontece na assembléia, é daí, sugere o filósofo, que o conceito utilizado é originário. ${ }^{21}$ Aristóteles, contudo, na sua sistematização da arte retórica, porque constrói uma noção de julgamento compreensiva, a incluir tanto o que ocorre na assembléia quanto no tribunal, amplia o conceito de deliberação e entende que há deliberação não apenas acerca das ações futuras, mas também das passadas. Tal ampliação se justificará, entretanto, em razão do componente de obscuridade e indeterminação em que estão imersas tanto as ações futuras, o que é por si evidente, quanto as passadas, no caso devido à controvérsia que acerca destas se estabeleceu entre as partes no tribunal. $\mathrm{O}$ que aconteceu, diz o filósofo, é de algum modo obscuro (asaphes, 1368a32) ${ }^{22}$ e por isso se torna matéria de deliberação e investigação. Dessa maneira, o julgamento público é instituído pelo regime democrático como deliberação/investigação, acerca de questões que, sendo de interesse comum mas obscuras, demandam exame e esclarecimento. Corfimando com esse entendimento, vemos em 1391b18-19 que o membro do tribunal e da assembléia é definido como aquele que julga as coisas investigadas (zetoumema) nos debates cívicos e que investiga (zetetai) as coisas em disputa no tribunal e em deliberação na assembléia.

O que julga no tribunal e na assembléia, encontrando-se num estado de ignorância, investiga com a finalidade de alcançar um saber. Ou seja, encontrando diante de si uma situação de antilogia, se pergunta por qual das alternativas apresentadas pelos discursos contraditórios deve decidir. Consistindo tais discursos em uma enumeração de doxai, a decisão por um deles assume a forma de adesão a certas opiniões. A decisão final do juiz reveste então a forma de crença (pistis), que é, segundo o De 
Anima, a forma de adesão própria à doxa. ${ }^{23}$ Há, contudo, aqui algo que pode trazer embaraço e por isso cabe examinar mais de perto. De um lado, o que persuade visa obter a adesão do que julga (lembremos que persuadir e julgar são conceitos inteiramente afins e complementares) para certa opinião, visa produzir nele certa crença. De outro lado, o julgamento assume, o autor destaca, o aspecto de investigação, ao final da qual sobrevem um saber, e também, importante nesse momento, uma verdade (aletheia). Convém lembrar que o filósofo em mais de uma oportunidade afirma que o julgamento público dá origem a uma verdade. Veja-se, por exemplo, 1354b10, onde o juiz discerne a verdade (theorein to alethes). ${ }^{24} \mathrm{E}$ mesmo a importante passagem de 1355a20-21, segundo a qual a retórica é útil para que no julgamento a verdade e a justiça vençam. ${ }^{25}$ Ora, se o saber que surge, uma vez finda a deliberação/investigação, não é, como afirma a Ética a Nicômaco, conhecimento (episteme), e sim uma forma de afirmação (phasis) denominada opinião, ${ }^{26} \mathrm{em}$ que sentido pode-se falar de verdade no domínio da opinião? Pois sabemos que o conceito de verdade é mais propriamente compatível com o domínio do conhecimento, com o discurso que diz respeito ao universal e necessário. Em que sentido pode haver verdade no domínio da opinião - daquilo que diz respeito ao que sempre pode ser diferente do que é -, e da retórica - a arte que tem por matéria própria as opiniões? Sobre esse ponto o que a Retórica nos diz é que verdade e opinião, verdade e retórica, não são pares conceituais inconciliáveis, ao menos não se se considera o sentido que o conceito de verdade assume no âmbito da teoria retórica. Uma resposta na direção de compatibilizar esses pares conceituais encontramos já na própria Ética, segundo a qual há uma correção (orthotes) de opinião que corresponde à verdade. ${ }^{27}$ No caso da prática oratória se chega à correção de opinião ou verdade sempre que o melhor e o justo são alcançados ao final do julgamento e vencem seus opostos. Temos nesse caso alcançado a boa deliberação (euboulia). ${ }^{28}$ Outra resposta encontramos na própria Retórica: "pertence à mesma capacidade ver ambos, $\mathrm{o}$ verdadeiro (to alethes) e o semelhante ao verdadeiro (to homoion toi alethei), (...) ser capaz de discernir as opiniões comumente admitidas (ta endoxa) é ser igualmente capaz de discernir a verdade (aletheian)", 1355a15-19. No âmbito da doxa (e das endoxa) e da retórica, especialmente se tivermos por referência e contraste a episteme, seria mais preciso falar em algo to homoion toi alethei (semelhante à verdade). Essa verdade 'mais fraca' e, talvez, apenas 'por analogia', que a arte da persuasão produz não ficará, entretanto, muito a dever para a verdade epistêmica, se considerarmos, por exemplo, a inserção institucional da retórica e as sérias implicações dos resultados dos julgamentos públicos para a vida da cidade e dos particulares. Implicações essas de que Aristóteles parecia, aliás, bem consciente ao destacar a dimensão de investigação da verdade assumida pelo julgamento público e ainda sua determinação em chamar a atenção para a utilidade própria da arte retórica, qual seja, fazer vir à luz e vencer a tese verdadeira e justa. ${ }^{29}$ 
Uma vez percorridas algumas das principais dimensões da situação de julgamento, resta-nos retomar nossa questão pendente, qual seja, entender a afirmação, que se lê em 1377b20-24, segundo a qual a impossibilidade de se restringir a persuasão à prova lógica e a necessidade do uso adicional das provas pelo ethos e pelo pathos decorrem do caráter de julgamento da situação em que o orador atua.

Tomemos primeiro a prova pelo ethos do orador. Apesar do quase absoluto silêncio de Aristóteles quanto à justificação da necessidade do uso da prova pelo ethos na persuasão, a passagem de 1356a5-9, que introduz essa prova, é rica em pistas. Ei-la: "Há persuasão através do caráter quando o discurso é falado de modo a fazer o orador digno de ser acreditado (axiopistos); pois acreditamos mais e mais rapidamente em pessoas honestas, em todos os assuntos em geral, e inteiramente nos casos em que não se tem certeza (to akribes me estin) e sim margem para duvidar (amphidoxein)". Em qualquer situação discursiva que tem por objeto a opinião, o caráter do que fala é um dado normalmente levado em consideração pelo interlocutor, para acreditar ou não no que ouve. Isto é, independentemente da clareza ou certeza que se tem acerca do assunto, sempre que alguém ouve um outro expondo-lhe uma opinião $\mathrm{X}$ relativa a esse assunto, levará em conta para acreditar em $\mathrm{X}$ a própria imagem que faz a respeito daquele que fala. $\mathrm{O}$ que Aristóteles parece querer nos dizer aqui é que o conceito de ethos do falante é algo sempre interveniente na adesão a uma opinião, isto é, na geração da pistis (crença), qualquer que seja a relação do ouvinte com o assunto discutido. Em se tratando de um assunto acerca do qual não se tem certeza (akribes me estin), e se duvida (amphidoxein), maior relevância assumirá o caráter do falante na formação da pistis do ouvinte, da adesão a uma opinião.

Parece que temos aqui então duas justificativas para o uso da prova pelo ethos. Uma delas seria o próprio fato de que na adesão a uma opinião, na pistis, intervém sempre e necessariamente a própria opinião que o ouvinte tem do falante. Se essa intervenção sempre e necessariamente acontece, parecerá natural que a arte retórica - que precisamente se move no universo das doxai - faça disso meio técnico, deliberado, de persuasão. A segunda justificativa, se nos ativermos à passagem acima, 1356a59, parece ser a prórpia inconclusividade da prova lógica. ${ }^{30} \mathrm{Ou}$ seja, dizendo o discurso retórico respeito àquilo que, embora seja na maior parte das vezes de determinada maneira, sempre pode ser diferente do que é, as premissas do argumento retórico, o entimema, não são necessárias, da mesma forma que não o é sua conclusão. Tudo o que se pode esperar da argumentação retórica é que seja verossímil, provável. ${ }^{31}$ As pisteis dia tou deiknynai (provas pelo demonstrar) ${ }^{32}$ são insuficientes para gerar a adesão a uma opinião porque a demonstração em retórica é inconclusiva. A incerteza e dúvida em que se vê o ouvinte não decorre apenas do fato de ter diante de si dois discursos 
contraditórios sobre o mesmo caso, mas também de que nenhum desses dois discursos pode apresentar-lhe uma demonstração final, necessariamente válida, das afirmações que faz. No máximo se poderá apresentar demonstração de que tais afirmações são plausíveis ou prováveis. Diversamente, no discurso da ciência, sendo possível a demonstração conclusiva, o ethos do mestre nenhum papel jogará na aceitação das conclusões dos silogismos pelo aluno. Tal conclusividade decorre, por sua vez, da própria natureza das premissas da ciência, que dizendo respeito ao que é sempre do mesmo modo, podem ser necessárias. A prova pelo ethos é então requerida pelo caráter de julgamento da situação em que atua o orador, em razão do fato de que se trata aí de julgar doxai, que, por um lado, dizem respeito ao que sempre pode ser outro, e, por outro, implicam numa forma de adesão, pistis, em cuja geração outros fatores que a mera demonstração intervêm.

Quanto à justificativa para o uso da prova pelo pathos, Aristóteles nos fornece pistas preciosas igualmente na passagem em que apresenta tal prova. Eis o que diz: "Há persuasão pelos ouvintes quando eles são levados a sentir emoção pelo discurso: pois nossos julgamentos não são os mesmos quando estamos tristes ou alegres, amistosos ou hostis" 1356a14-16. Acrescenta em outro momento que o público deve ser posto em certa disposição emocional uma vez que "as coisas não aparecem (phainetai) da mesma forma aos que estão amistosos e aos hostis, nem aos que estão irados ou calmos, mas, ou parecem inteiramente diferentes, ou diferentes em grau: para o que está amistoso, a pessoa acerca da qual julga parece não ser culpada ou apenas de um modo leve: para o que está hostil, o oposto; e para uma pessoa sentindo forte desejo e esperança, se algo no futuro é à medida dos seus desejos, parece que ocorrerá e será bom; para o insensível e o mal-humorado se passa exatamente", 1377b31-1378a5. Nossos julgamentos, o modo como as coisas nos aparecem (phainetai), são função do estado emocional em que nos encontramos. Note-se que as emoções são definidas na Retórica como causa da mudança de julgamento. ${ }^{33}$ Ora, julgar nada mais é que aderir a uma certa opinião. Na geração da adesão, pistis, intervém, portanto, não apenas a imagem que se tem de quem fala, mas igualmente o estado emocional em que nos encontramos. As emoções, sugere o autor em 1354b11, têm o poder de obscurecer (episkotein) o julgamento. ${ }^{34}$ Podemos - invertendo o argumento e talvez tomando alguma liberdade ao texto, afirmar que as emoções, se têm o poder de obscurecer o julgamento, teriam também o poder de esclarecê-lo. Uma vez que as emoções sempre e necessariamente intervêm na produção da pistis, da adesão a uma certa opinião, parecerá, mais uma vez, natural que arte retórica faça da atuação sobre elas meio técnico, deliberado, de persuasão. Notese que, embora toda e qualquer emoção influa no julgamento, na adesão a certa opinião, apenas certas emoções têm o poder de esclarecê-lo. Quais seriam elas? Aquelas 
que seriam apropriadas à correta opinião, à verdade, sobre o assunto em discussão. Somente essas teriam o poder de esclarecer o julgamento, de iluminar, por assim dizer, a razão acerca de qual dos dois discursos contrários é mais verdadeiro. Nesse sentido, o orador que defende a opinião verdadeira, se souber provocar a emoção mais compatível com essa opinião, produzirá a clareza de juízo e a adesão. Será, entretanto, sempre possível excitar as emoções dos ouvintes, ainda que não seja para fazê-los ver as coisas do ângulo correto, mas apenas para conduzi-los a falsas opiniões: "o ouvinte compartilha sempre as mesmas emoções que o orador, mesmo que este nada diga. Em conseqüência, muitos impressionam os ouvintes com mero barulho", 1408a23-25. É para evitar uma falsa adesão, a crença numa opinião falsa - nem a melhor, nem a mais justa - que o orador deve usar a persuasão pelo pathos do ouvinte.

A prova pelo pathos será necessária numa situação de julgamento, tal como a prova pelo ethos, porque se trata aí de julgar opiniões, vale dizer, de ter elementos para saber às quais aderir, outros que os fornecidos pela prova lógica.

\section{Notas}

* Professora Doutora de Filosofia da Faculdade de Educação da USP.

1 O termo pisteis, de sentido variado ao longo da Retórica, poderia, nesse uso particular, ser traduzido como meio de persuasão, como o fizeram alguns tradutores Optamos aqui, como alguns estudiosos, pela tradução por provas, por entender que dá conta melhor das múltiplas implicações que o autor quer conferir ao termo.

2 "Das provas, umas são não-técnicas (atechnoi) e outras técnicas (entechnoi). Pelas primeiras entendo todas as que não foram produzidas por nós, mas já existiam, tais como as testemunhas, os depoimentos de escravos extraídos sob tortura, os contratos e outras semelhantes; entendo pelas últimas todas as que se podem preparar por método e por nosso esforço. De sorte que é necessário utilizar as primeiras e inventar as últimas. As provas fornecidas pelo discurso são de três espécies: umas estão no caráter do orador (ai en toi ethei tou legontos), outras no dispor o ouvinte de uma certa maneira (ai en toi akroaten diatheinai pos) e outras no próprio discurso, por demonstrar ou parecer demonstrar algo (ai en autoi toi logoi, dia tou deiknynai e phainetai deiknynai)." Retórica, 1355b35-56a4. (Quando não referirmos a obra de Aristóteles, tratar-se-á da Retórica.) Para as provas não-técnicas vide $1375 \mathrm{a} 25$ e segs.

3 Para a noção de técnica discursiva de verdade vide Trois techniques de vérité dans la Grèce Classique, Aristote et l'argumentation, Hermes, 15,1995, p.42 e segs. A aproximação da retórica com a dialética e a ciência, vale recordar, é inteiramente procedente. O próprio filósofo faz reiteradamente ao longo da Retórica a analogia dessa arte com aquelas duas técnicas discusivas, seja para assemelhá-las, seja para distanciá-las. 
4 A bem da verdade, as provas pelo ethos e pelo pathos usam também de meios argumentativos, entretanto, estes não têm nelas a mesma centralidade que têm na prova lógica. Nesta, que é chamada em 1356 b6 prova pelo demonstrar (dia tou deiknynai), a argumentação ocupa o primeiro plano e é usada com a finalidade direta de demonstrar a verdade de certa tese $X$, relativa aos pontos principais da discussão. Por sua vez, naquelas duas provas a argumentação é usada de forma auxiliar, por exemplo fazendo com que o ouvinte adira a certa opinião Y, opinião essa que produzirá nele, a seguir, uma imagem do ethos do orador ou um pathos. Estes últimos provocarão, por sua vez, a aceitação da tese $\mathrm{X}$ - relativa aos pontos principais da discussão - como verdadeira.

5 Para essa distinção vide Ética a Nicômaco, 1102 a29 e segs.

6 Para melhor entender a natureza particular da arte retórica podemos compará-la à arte poética. Poderíamos dizer que o discurso poético, no caso da tragédia, apelaria também à parte não-racional da alma, uma vez que a comoção - a piedade e o temor - do espectador é sua finalidade primeira. Contudo, diferentemente da retórica, a tragédia não tem como objetivo primordial a produção de uma convicção de verdade no interlocutor. Ela pretende somente produzir nele o efeito do belo ou do prazer e dor. Ela não tem a intenção de transmitir uma opinião verdadeira ao ouvinte.

7 "Observo e noto duas espécies de homem: um, eu o vejo capaz de praticar essa ironia em reuniões públicas, em longos discursos, diante de multidões; ao passo que o outro, em reuniões privadas, cortando seu discurso em argumentos breves, obrigando seu interlocutor a se contradizer" Sofista, 268b1-4.

8 Eis a passagem na íntegra: "uma vez que o uso do discurso persuasivo está dirigido a um julgamento (pois sobre o que sabemos e já julgamos não há mais necessidade de discurso), uma vez que há julgamento mesmo se alguém usa o discurso para se dirigir a uma única pessoa, exortando-a ou dissuadindo-a, como, por exemplo, fazem os que advertem ou persuadem (pois pelo fato de um ouvinte ser único, não significa que seja menos juiz, visto que um juiz é, por assim dizer, simplesmente alguém que deve ser persuadido) e quando se fala contra um oponente e contra uma proposição, o mesmo é verdadeiro (já que forçosamente é preciso empregar o discurso para refutar os argumentos contrários, contra os quais se fala como se fossem dirigidos a um oponente); o mesmo acontece nos discursos epidíticos (neste caso o discurso é dirigido ao espectador como se fosse um juiz), contudo, em geral somente é juiz, no sentido estrito do termo, aquele que julga as questões em disputa nos debates cívicos (pois ele investiga os fatos em disputa e os assuntos em deliberação), e uma vez que os caracteres correspondentes às diferentes constituições foram discutidos anteriormente, em conseqüência a definição de como e por quais meios devem-se fazer discursos éticos deveria ser completa”. W. M. A. Grimaldi (Aristotle, Rhetoric II, A Commentary, New York: Fordham University Press, p. 225-228) chama atenção para os problemas de interpretação que essa passagem introduz, devido a sua construção sintática. Alguns estudiosos entenderam que a conclusão do raciocínio se inicia na linha 1391 b21 ("e uma vez que os caracteres correspondentes..."), contudo, não viram conexão lógica entre ela e o que antecede. Pensaram então se tratar de uma adição tardia de Aristóteles, ou de uma passagem que se encontraria mais adequada em outro ponto da Retórica (por exemplo, próximo a 1377b20-24). Tentamos aqui dar um sentido à passagem tal como chegou a nós, entendendo que nela Aristóteles reitera a 
idéia exposta em 1377b20-24, segundo a qual, desde que a retórica tem sede em instituições cujo centro é ocupado por uma atividade particular, um julgamento, não bastaria fazer apenas uso da persuasão demonstrativa (apodeiktikos,1377b23), isto é, da prova lógica, mas seria necessário também persuadir pelo ethos e pelo pathos. Alguns comentadores quiseram mesmo crer que tous logous ethikous da linha 1391 b22 inclui as duas provas e não apenas a prova pelo ethos. Tal é também nossa convicção. Em 1366a10, contudo, essa mesma expressão aparece inequivocamente designando somente esta prova.

9 Note-se que nessa referência ao gênero epidítico, afirma-se que o ouvinte é um juiz, embora não no sentido pleno em que o participante da assembléia ou do tribunal o é. Podemos concluir disso que a função persuasiva do discurso não se realiza igualmente nos três gêneros, e sim de modo mais acabado apenas nos gêneros deliberativo e judiciário. Na verdade, tal distinção está no espírito de outras partes da Retórica, onde se apresenta o espectador dos discursos epidíticos como não tendo as mesmas atribuições que o membro da assembléia ou tribunal. Podemos inferir assim que, embora o autor se esforce por formular uma teoria geral da retórica que compreenda o gênero epidítico - o que seria compatível com uma postura realista de reconhecimento de uma prática existente -, ele reconhece igualmente as limitações da capacidade compreensiva de uma tal teoria. Em mais de um caso suas ponderações são aplicáveis unicamente aos gêneros deliberativo e judiciário. Logo ao início do livro I, por exemplo, em 1358b2-7, a qualificação de juiz é reservada apenas ao participante da assembléia e tribunal, tendo sido excluído o ouvinte do discurso epidítico: "É necessário que o ouvinte seja um espectador ou um juiz, e, no último caso, um juiz dos acontecimentos passados ou futuros. $\mathrm{O}$ membro de uma assembléia democrática é exemplo de alguém julgando acerca dos acontecimentos futuros, o membro do tribunal exemplo de alguém julgando o passado. O espectador é exemplo de alguém julgando a habilidade do orador."

10 "Cada sentido se relaciona então com seu sensível próprio, reside no órgão do sentido enquanto tal e discerne diferenças no dito sensível próprio; por exemplo, a visão discrimina (krinei) entre o branco e o preto e o gosto entre o amargo e o doce", De Anima, 426b8-12. Th. Ebert em Aristotle on what is done on perceiving, Zeitschrift für Philosophische Forschung, n. 37, 1983, nota que o termo grego krinein tem duas acepções: uma primeira, discriminar/discernir, e uma segunda, julgar/decidir. De acordo com ele, no contexto do De Anima a primeira acepção deveria ser sempre a preferida numa tradução, já que a percepção sensível é a atividade de distinguir, separar, qualidades sensíveis opostas. A acepção decidir se aplicaria antes ao uso do termo no contexto judiciário e político, onde embora se trate ainda de discriminar entre possibilidades opostas em relação aos fatos passados e futuros, a tarefa se mostra bem mais complexa, devendo os juízes proceder a uma investigação completa do caso e não simplesmente aplicar uma certa lei.

11 Por exemplo, os papéis de réu e vítima no tribunal e dos (pelo menos) dois oradores antagonistas na assembléia.

12 Sobre os pontos em disputa vide Retórica, 1417 b25 e seguintes: "É necessário que as provas sejam demonstrativas. Visto que os pontos em debate são quatro, é útil formular a demonstração sobre o ponto que está em questão. Por exemplo, se a questão em causa 
FRANCISCO, Maria de Fátima Simões. C Caráter, emoção e julgamento na Retórica de Aristóteles.

for relativa à negação da ocorrência de algo, é necessário no julgamento, antes de mais nada, a sua demonstração; e se for que não causou prejuízo, ou que não foi tão grave ou que foi justa, ela deve recair sobre estes aspectos; de modo idêntico, se o ponto em questão for sobre um fato que efetivamente ocorreu. (...) No gênero deliberativo, poderse-á discutir se o que se recomenda não terá lugar, ou que ocorrerá, mas que não será justo nem vantajoso nem de tamanha importância."

13 "Eis as fontes adequadas de exortação e dissuasão, elogio e censura, acusação e defesa, e os tipos de opinião e proposição úteis para sua expressão persuasiva”, 1377b17. "Uma vez que há um fim diferente para cada gênero de discurso e as opiniões e premissas foram apresentadas para todos..." 1391 b24.

14 "É preciso ser capaz de argumentar persuasivamente sobre coisas contrárias, como também acontece nos silogismos; não para fazer uma e outra coisa - pois não se deve persuadir do que é imoral - mas para que não nos escape o real estado da questão e para que, sempre que alguém argumentar contra a justiça, nós próprios estejamos habilitados a refutar seus argumentos. Ora, nenhuma das outras artes obtém conclusões sobre contrários por meio de silogismos a não ser a dialética e a retórica, pois ambas se ocupam igualmente dos contrários", 1354a30-35.

15 Vide $1357 \mathrm{a} 2$.

16 Ética a Nicômaco, 1142 b3.

17 "Deliberar implica investigar (zetein) e calcular (logizetai)", Ética a Nicômaco, 1142 b3. “deliberamos acerca do que está em nosso controle e pode ser alcançado pela ação”, idem, $1112 \mathrm{a} 30$.

18 "Imaginação na forma dos sentidos é encontrada, como dissemos, em todos os animais, mas a imaginação deliberativa apenas no calculativos; pois decidir se se deverá fazer isto ou aquilo demanda imediatamente cálculo, e deve-se medir por um padrão simples, pois busca-se o maior bem", De Anima, 434a8-9.

19 "Deliberamos acerca de coisas que acontecem de uma certa forma na maior parte das vezes, mas cujo resultado é obscuro (adelois), e daquelas em que este é indeterminado (adioriston)", Ética a Nicômaco, 1112b8-10.

20 "A maior parte das coisas sobre que se dão os julgamentos (kriseis) e as investigações (skepseis) pode ser diferente do que é, pois as pessoas deliberam (bouleuontai) e investigam (skopousi) suas ações (prattousi), sendo todas as ações de tal caráter e nenhuma delas necessária.", 1357a25-7. "Deliberamos (bouleuometha) acerca de coisas que parecem poder admitir duas possibilidades; pois ninguém delibera acerca do que não pode ser diferente no passado, futuro ou presente, pelo menos não se pensar ser esse o caso", 1357a6-7.

21 Vide Ética a Nicômaco, 1141b23-1142a2.

22 "Pois o que aconteceu é de algum modo obscuro (asaphes)", $1368 \mathrm{a} 32$.

23 "Toda opinião (doxe) implica crença (pistis), crença implica que fomos persuadidos (pepeisthai), e o que persuade é a razão (logos)”, 428a22-23. Seguimos a tradução sugerida por Th. Ebert no artigo supra citado. 
24 "Na sua apreciação dos fatos, intervêm muitas vezes a amizade, a hostilidade, e o interesse pessoal, com a conseqüência de não mais conseguirem discernir a verdade (theorein to alethes) com exatidão e de o seu juízo ser obscurecido (episkotein) por um sentimento egoísta de prazer ou de dor", 1354b10-11.

25 "A retórica é útil porque a verdade e a justiça são por natureza mais fortes que os seus contrários, de sorte que, se os julgamentos não se fizerem como convém, a verdade e a justiça serão necessariamente vencidos pelos seus contrários, e isso é digno de censura”, 1355a20-21.

26 "Deliberação não é conhecimento (episteme): pois os homens não investigam o que conhecem”, Ética a Nicômaco, 1142b1. "A opinião já ultrapassou a fase de investigação e é uma forma de afirmação (phasis), ao passo que o homem que delibera, quer delibere bem ou mal, está investigando e calculando algo", idem, 1142 b14.

27 “Correção de opinião é a verdade (doxes orthotes aletheia)", Ética a Nicômaco, 1142 b14.

28 "É, portanto, essa espécie de correção na deliberação que constitui a boa deliberação (euboulia), isto é, aquela que tende a alcançar um bem”, Ética a Nicômaco, 1142b20-23.

29 Vide 1355a20-21, supre nota 25.

30 M. Burnyeat chamou atenção justamente para esse aspecto. Segundo ele, o entimema é um "argument in a context where certainty and conclusive proof are not to be had (1356a78 ; 1357a1-2), yet a judgment must be made (1358a36-b8; 1377b21-78a6; 1391b8-20; 1420b2-3)", Enthymeme: Aristotle on the Logic of Persuasion, in D. J. Furley \& A. Nehamas (eds.), Aristotle's Rhetoric: Philosophical Essays, Princeton: Princeton University Press, 1994, p. 13.

31 Há aqui uma longa discussão - que tem atraído a maior parte da atenção dos comentadores da Retórica - acerca de como interpretar a natureza das premissas e conclusão do entimema, que é dito ser composto de eikota, 1357a30. Não podendo nos deter nessa discussão, remetemos a alguns estudos: M. Burnyeat em Enthymeme: Aristotle on the Logic of Persuasion, in D. J. Furley \& A. Nehamas (eds.), Aristotle's Rhetoric, Philosophical Essays, Princeton: Princeton University Press, 1994, p. 3-55; F. Wolff, Trois Techniques de Vérité dans la Grèce Classique, Aristote et l'Argumentation, Hermès, n. 15, 1995, p. 41-71; E. Ryan em Aristotle's Theory of Rhetorical Argumentation, Montreal: Les Editions Bellarmin, 1984 e J. H. McBurney em The Place of the Enthymeme in Rhetorical Theory, in K.V. Ericson (ed.), Aristotle: The Classical Heritage of Rhetoric, Scarecrow, Metuchen, 1974, p. 117-140.

32 Vide 1356 a3.

33 Eis a definição de emoção (pathos) dada pela Retórica: "as emoções são aquelas coisas que, ao se modificarem, fazem com que as pessoas alterem seus julgamentos e que são acompanhadas de prazer e dor", 1378a19-22. As emoções foram, a propriamente falar, retorizadas, reduzidas à dimensão que importa à retórica. Aliás, é dessa maneira que se deve entender os capítulos do livro II que tratam delas.

34 Vide Retórica, 1354b10-11, supra nota 24. 
FRANCISCO, Maria de Fátima Simões. Character, emotion and judgement in Aristotle's Rhetoric.

ABSTRACT: In his theory of rhetorical art Aristotle sees three kinds of proofs through which the speaker persuades. We are interested in investigating two of them - that which develops through the speaker's character and that which develops through the hearer's emotion - and in understanding in what way they are related to the judgement situation in which the speaker practices his art. This situation is examined in some of its aspects. After this we try to understand the philosopher's justification for the need in using those proofs in rhetorical art.

KEY WORDS: proofs; character; emotion; judgement; antilogy; deliberation; investigation; opinion; belief. 